\title{
Causes and amelioration of nutrient deficiencies in cutovers of cedar-hemlock forests in coastal British Columbia
}

\author{
by C.E. Prescott ${ }^{1}$ G.F. Weetman ${ }^{1}$ and J.E. Barker ${ }^{2}$
}

Poor growth of conifer regeneration occurred on sites formerly occupied by old-growth cedar-hemlock $(\mathrm{CH})$ forests in coastal British Columbia, $5-8$ years after clearcutting and slashburning. Symptoms included chlorotic foliage and growth check of Sitka spruce, western hemlock, western red cedar and amabilis fir, coincident with the expansion of the ericaceous shrub, salal, on the cutovers. Fertilization trials identified $\mathrm{N}$ and $\mathrm{P}$ deficiencies as the cause of the growth check of conifers, and additions of $300 \mathrm{~kg} \mathrm{~N} \mathrm{ha}^{-1}$ and $100 \mathrm{~kg} \mathrm{P} \mathrm{ha}^{-1}$ significantly improved tree growth rates. Equivalent growth responses were achieved with additions of sewage sludge and fish silage. Burning, cultivating, liming, higher planting densities or herbicide application, were less effective in promoting conifer growth. The nutrient deficiencies in conifers on $\mathrm{CH}$ cutovers were the result of two factors: low nutrient availability in soil and humus, and competition and interference from salal. Salal immobilized substantial amounts of $\mathrm{N}$ in biomass and an in vitro study suggested it was able to use organic forms of $\mathrm{N}$ through its mycorrhizal fungi. The mycorrhizae of salal also interfered with those of hemlock, which further reduced their ability to take up nutrients. High concentrations of phenolic acids were associated with salal, which interfere with mineralization and uptake of $\mathrm{N}$. The low availability of $\mathrm{N}$ and $\mathrm{P}$ in $\mathrm{CH}$ cutovers originated in forest floors of the old-growth forests prior to clearcutting. Nutrient availability was low in all layers of the forest floor in $\mathrm{CH}$ forests, and this appeared to result from three main factors. First, cedar litter contains less $\mathrm{N}$ and more decay-resistant material than other species, and produces forest floors with low rates of $\mathrm{N} \mathrm{min-}$ eralization. Second, the forest floors in $\mathrm{CH}$ forests are wetter and have less soil fauna than in HA forests, leading to incomplete decomposition and mineralization of $\mathrm{N}$. Third, the salal understorey in $\mathrm{CH}$ forests interferes with mineralization of $\mathrm{N}$ through the production of tannins.

Key words: growth check, fertilization, herbicide, ericaceous shrub, sewage sludge, mycorrhizae, allelopathy, nitrogen availability, nutrient cycling, NMR analysis
Une faible croissance de la régéneration résineuse a été observée sur les sites anciennement couverts par de vieilles forêts de cèdres et de pruches $(\mathrm{CP})$ de la région côtière de la Colombie-Britannique, 5 à 8 années après la coupe à blanc et le brûlage des résidus. Les symptômes observés comprendraient le feuillage chlorosé et l'hypertrophie de la croissance chez l'épinette de Sitka, la pruche de l'ouest, le cèdre rouge de l'ouest, le sapin gracile, la coïncidence avec la progression d'un éricacée arbustif, le salal sur les parterres de coupe. Des essais de fertilisation ont identifié des carences en $\mathrm{N}$ et en $\mathrm{P}$ comme étant la cause de l'hypertrophie de la croissance des coniferes, et l'apport de 300 $\mathrm{kg} / \mathrm{ha}$ de $\mathrm{N}$ et de $100 \mathrm{~kg} / \mathrm{ha}$ de $\mathrm{P}$ a significativement amélioré le taux de croissance des arbres. Des réactions équivalentes de croissance ont été atteintes par l'apport de boues résiduelles de traitement des caux et de résidus de transformation de poisson. Le brûlage, la préparation du sol, l'apport de chaux, des densités plus élevées de plantation, se sont avérés moins efficaces pour accroître la croissance des résineux. Les carences en éléments nutritifs des conifêres des parterres CP sont le résultat de deux facteurs: la faible disponibilité des éléments nutritifs dans le sol et l'humus, ainsi que la compétition et l'interférence causées par le salal. Le salal immobilisait de grandes quantités de $\mathrm{N}$ dans la biomasse et une étude in vitro suggérait qu'il était capable d'utiliser des formes organiques de $\mathrm{N}$ par l'entremise de champignons mycorrhizateurs. Les micorrhizes du salal interféraient également avec celles de la pruche, ce qui réduisait d'autant plus la capacité d'intégrer les éléments nutritifs. De fortes concentrations d'acides phénoliques ont été associées avec le salal, ce qui empêche la minéralisation et l'intégration de $\mathrm{N}$. La faible disponibilité de $\mathrm{N}$ et de $\mathrm{P}$ dans les parterres de $\mathrm{CP}$ provenait des sols forestiers des vieilles forêts avant même la coupe. La disponibilité des éléments nutritifs était faible dans touters les couches du sol forestier des forêts de $\mathrm{CP}$, et cela semblait être le résultat de trois principaux facteurs. En premier lieu, la litière de cèdre contient moins de $\mathrm{N}$ et plus de substances résistantes à la décomposition que les autres espèces, et entraînait la formation de sols forestiers ayant de faibles taux de N minéralisé. En second lieu, les sols forestiers des forêts de CP étaient plus humides et comportait moins d'éléments de la faune pédologique que dans les autres forêts, provoquant ainsi une décomposition et une minéralisation incomplète de N. En troisième lieu, le couvert de salal dans les forêts de CP interrompt la minéralisation de $\mathrm{N}$ par la production de tanins.

Mots clés: hypertrophie de la croissance, fertilisation, phytocide, éricacée arbustif, boues résiduelles, mycorrhizes, allélopathie, disponibilité de l'azote, cycle des éléments nutritifs, analyse de l'azote minéralisée

\section{Introduction}

This report presents an overview of the findings of the Salal Cedar Hemlock Integrated Research Program (SCHIRP), which are described in more detail by Prescott and Weetman (1994). The objective of this decade-long research effort was to determine the underlying causes of poor growth of regenerating

${ }^{1}$ Forest Science Department, University of British Columbia, Vancouver, British Columbia, Canada V6T 1 Z4.

${ }^{2}$ Western Forest Products Ltd., 2300 - 1111 W. Georgia St., Vancouver, British Columbia, Canada V6E 4M3. western red cedar (Thuja plicata Donn.), western hemlock [Tsuga heterophylla (Raf. Sarge), amabilis fir (Abies amabilis Dougl.) and Sitka spruce (Picea sitchensis (Bong.) Carr.] on cutovers of coastal old-growth cedar-hemlock forests invaded by salal. Logging of coastal old-growth cedar-hemlock $(\mathrm{CH})$ forests during the 1960s generated substantial areas of cutovers which regenerated very slowly with cedar and hemlock. To achieve more rapid regeneration, sites were slashburned to reduce slash accumulations and the heavy cover of the ericaceous shrub, salal (Gaultheria shallon Pursh), and planted with Sitka spruce. The spruce plantations grew well initially, but by age six to eight years, they showed signs of severe nutrient defi- 
ciency and growth rates declined markedly. Cedar appeared to be less influenced by the nutritional problems on these sites and consequently cedar was planted thereafter. However, growth check and associated chlorosis were apparent in all species five to eight years after clearcutting and slashburning, coincident with the expansion of salal on $\mathrm{CH}$ sites. The problem did not occur on adjacent sites formerly occupied by secondgrowth forests of hemlock and amabilis fir (HA).

Research was conducted to determine silvicultural practices to alleviate the growth problem, and to understand the fundamental cause of the poor nutrition of trees. Initial field trials demonstrated deficiencies of $\mathrm{N}$ and $\mathrm{P}$ as the cause of poor growth. Subsequent studies examined the decline in $\mathrm{N}$ and $\mathrm{P}$ availability following clearcutting and burning, and the role of salal in contributing to poor conifer growth. The cause of poor nutrient supply was investigated by comparing nutrient cycling in old-growth $\mathrm{CH}$ forests with second-growth forests of $\mathrm{HA}$ which do not have low nutrient supply after clearcutting.

\section{Study Area}

The study area is on northern Vancouver Island, between the towns of Port Hardy and Port McNeill, $\mathrm{BC}\left(50^{\circ} 60^{\prime} \mathrm{N}\right.$ lat., $127^{\circ} 35^{\prime} \mathrm{W}$ long.) at elevations of less than $300 \mathrm{~m}$. The area is within the very wet maritime subzone of the Coastal Western Hemlock (CWH) biogeoclimatic zone (Pojar et al. 1991), and has a maritime climate with mild winters and cool moist summers. Mean annual precipitation is about $1700 \mathrm{~mm}, 65 \%$ of which occurs between October and February, and almost all is rain. Mean annual temperature is $7.9^{\circ} \mathrm{C}$, and daily averages range from $2^{\circ} \mathrm{C}$ in January to $14^{\circ} \mathrm{C}$ in August. The surface geological material is deep unconsolidated morainal and fluvial outwash material overlying sedimentary and volcanic bedrock.

The distribution of forest vegetation across this area varies with topography, geological substrate, and the type and frequency of natural disturbance. Wildfire is uncommon, and the predominant natural disturbance is windthrow. The forests are largely composed of western red cedar, western hemlock and amabilis fir, with some Sitka spruce on the outer coast and lodgepole pine (Pinus contorta var. contorta Dougl.) on poorly drained sites. On well-drained to somewhat imperfectlydrained middle or upper slope situations, the forests occur in two distinct types: 1) old-growth $\mathrm{CH}$ forests dominated by western red cedar up to 1000 years old with a small component of western hemlock, and 2) second-growth HA forests dominated by western hemlock and amabilis fir, that are even-aged and originated following a windstorm in 1906. Lewis (1982) could not distinguish between the two forest types on the basis of topography or mineral soil characteristics, and included them in the same ecosystem association. He further hypothesized that $\mathrm{HA}$ forests were a seral stage of $\mathrm{CH}$ forests. Both types have deep mor forest floors, generally of greater depth in the $\mathrm{CH}$ than the HA type (Germain 1985). Soils are duric or orthic Humo-Ferric Podzols.

\section{Silvicultural Trials}

Experiments were established in $\mathrm{CH}$ cutovers to test the effectiveness of a variety of treatments for improving the growth of conifers. Treatments included fertilization, scarification, weed control, planting density manipulation, burning and liming. The strategy was similar to that applied to the problem of "heather check" in the U.K. and Ireland (Carey 1977; Taylor 1987), namely to increase tree growth leading to crown closure and shading out of salal (Messier et al. 1989). It is hoped that once nutrient competition from salal is reduced, tree growth will be sustained.

\section{Fertilization Trials}

Single-tree screening trials were conducted on Sitka spruce and western red cedar on $\mathrm{CH}$ sites five to eight years after planting (Weetman et al. 1989a, 1989b). Numerous combinations of N,P and $\mathrm{K}$ were applied in the spring to circular plots of $5 \mathrm{~m}$ radius centered on the test tree. Fertilizer combinations were generally replicated five times. The first-year response data were analyzed using foliar vector analysis. The results indicated that the growth of both species was limited by $\mathrm{N}$ and $\mathrm{P}$ but not by $\mathrm{K}$. The growth limitation of spruce was much greater than that of cedar. Fertilizer doses of $200-300 \mathrm{~kg} \mathrm{~N} \mathrm{ha}^{-1}$ and $50-100 \mathrm{~kg}$ $\mathrm{P} \mathrm{ha}^{-1}$ were identified as optimum treatments.

In the conventional plot trials, square plots $(25$ or $30 \mathrm{~m}$ on a side) of pure spruce, cedar or western hemlock were handfertilized five to eight years after planting (Weetman et al. 1989a, 1989b; Thompson and Weetman 1992a). Spruce plots received one of six treatments (all numbers are $\mathrm{kg} \mathrm{ha}^{-1}$ ): $0 \mathrm{~N}, 0 \mathrm{P}$ (control); $100 \mathrm{~N}+50 \mathrm{P} ; 200 \mathrm{~N}+50 \mathrm{P} ; 300 \mathrm{~N}+50 \mathrm{P} ; 300 \mathrm{~N}+150 \mathrm{P}$; or $300 \mathrm{~N}+50 \mathrm{P}+91 \mathrm{~K}$ plus a micronutrient mix. Cedar and hemlock plots received one of 12 treatments; $0,100,200$ or 300 $\mathrm{N}$, combined with $0 \mathrm{P}, 100 \mathrm{P}$, or $100 \mathrm{P}$ plus micro-nutrients. Each treatment was replicated three times to give 18 plots of spruce and 36 plots each of cedar and hemlock. The results indicated that growth of all three species was limited by $\mathrm{N}$ and $\mathrm{P}$ deficiencies. The growth limitation was greatest for spruce and least for cedar. For spruce, the greatest growth rates were recorded in the $300 \mathrm{~N}+150 \mathrm{P}$ and $300 \mathrm{~N}+50 \mathrm{P}+$ micronutrient treatments. For cedar and hemlock, the greatest growth response was in the 200 or $300 \mathrm{~N}$ plus $100 \mathrm{P}$ (with or without micronutrients) treatments. The growth response was greatest in the second to fourth years following fertilization of spruce and hemlock, but it continued for at least seven years in all three species (Fig. 1). Combined data from these experiments indicated a strong correlation between relative growth rate and foliar $\mathrm{N}$ concentrations (Fig. 2). Fertilization with $\mathrm{N}$ and $\mathrm{P}$ significantly accelerated crown closure (\% of ground area shaded by crowns) (Fig. 3). Six years following treatment with $300 \mathrm{~kg} \mathrm{Nha}^{-1}$ plus $\mathrm{P}$, crown closure exceeded $70 \%$, while crown closure averaged $30 \%$ in control plots.

Operational fertilization experiments were conducted in 1986 in four 50 ha trials in $\mathrm{CH}$ cutovers (Thompson and Weetman 1992a). Fertilizer was applied by helicopter at $300 \mathrm{~kg} \mathrm{~N} \mathrm{ha}^{-1}$ plus $100 \mathrm{~kg} \mathrm{P} \mathrm{ha}^{-1}$ to cedar, and $225 \mathrm{~kg} \mathrm{~N} \mathrm{ha}^{-1}$ plus $75 \mathrm{~kg} \mathrm{P}$ $\mathrm{ha}^{-1}$ to spruce. Twenty-six circular plots were established, 4 to $12 \mathrm{~m}$ in radius (smaller plots in denser stands). Most plots contained spruce, cedar and hemlock. For all three species, operational fertilization significantly increased growth rates. The growth response to fertilization was greatest for spruce, very large for hemlock and modest for cedar.

To determine the efficiency of fertilization, ${ }^{15} \mathrm{~N}$-labelled ammonium sulphate fertilizer was applied to single tree plots of Sitka spruce, western red cedar and western hemlock on a $\mathrm{CH}$ cutover (Chang et al. in press). Salal was manually removed from half of the plots. Total ${ }^{15} \mathrm{~N}$ recovery in the plant-soil system after two growing seasons was $54-83 \%$. Most of the 

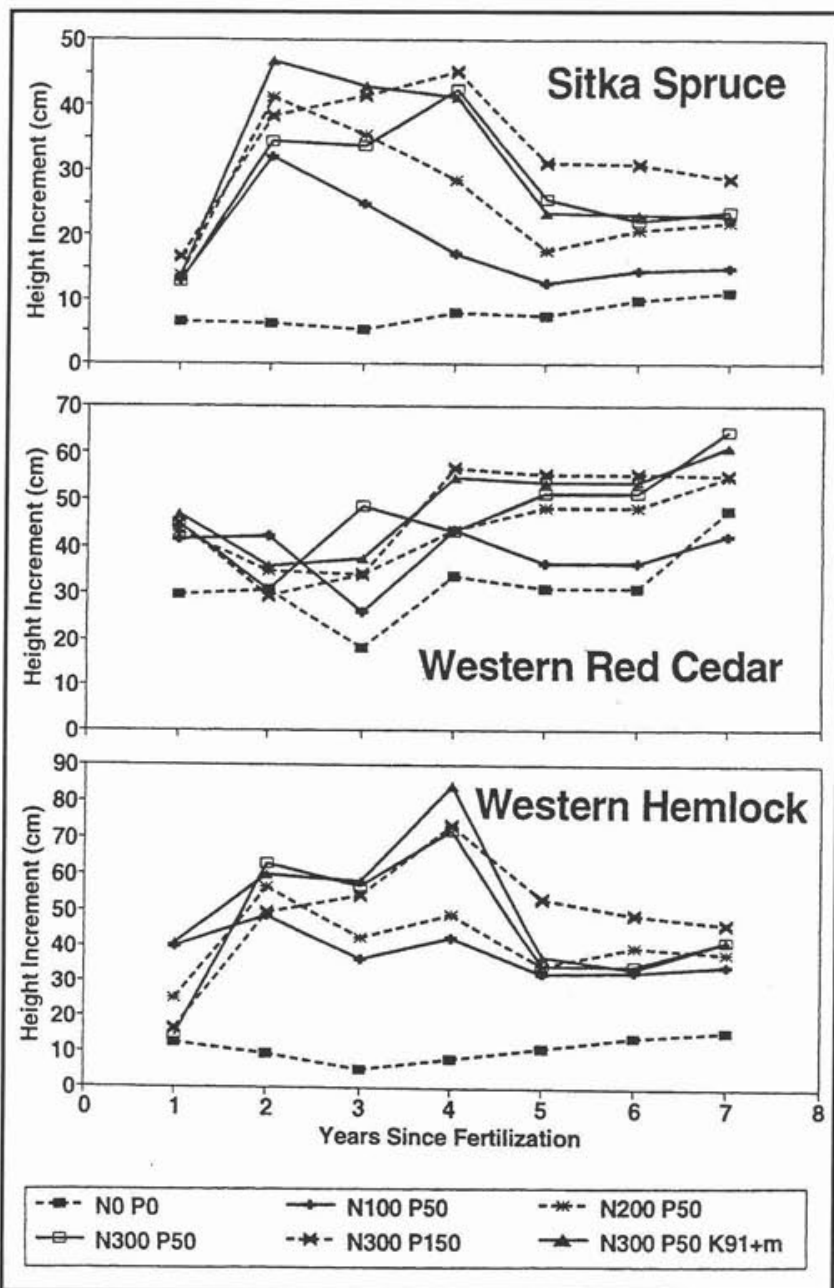

Fig. 1. Height increment of spruce, cedar and hemlock on coastal cedarhemlock cutovers after fertilization with $\mathrm{N}, \mathrm{P}, \mathrm{K}$ and micronutrients.

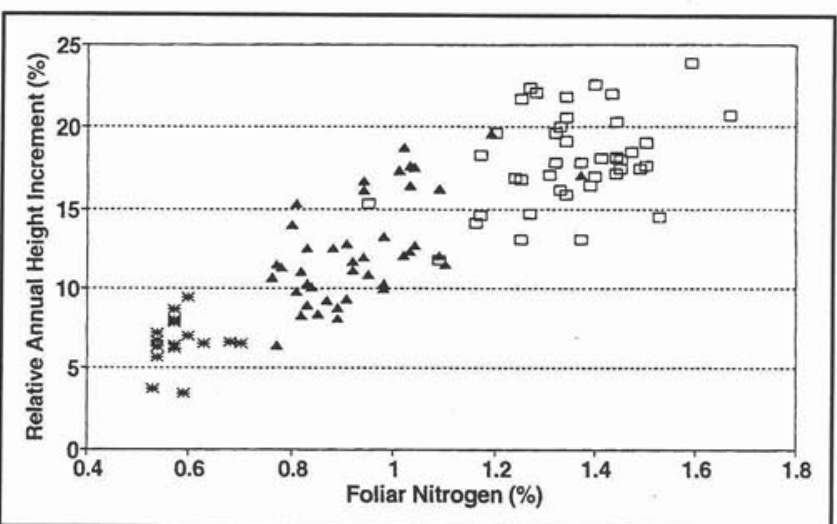

Fig. 2. Relationship between height growth and foliar $\% \mathrm{~N}$ of conifers on $\mathrm{CH}$ cutovers.

${ }^{15} \mathrm{~N}$ recovered was immobilized in the soil $(62-83 \%)$. In the plots with salal, $20-31 \%$ of the ${ }^{15} \mathrm{~N}$ was immobilized in understorey vegetation, and only $2-5 \%$ was in the trees. In the plots from which salal had been removed, $8-18 \%$ of the ${ }^{15} \mathrm{~N}$ was in the trees and only $2-5 \%$ was in the understorey.

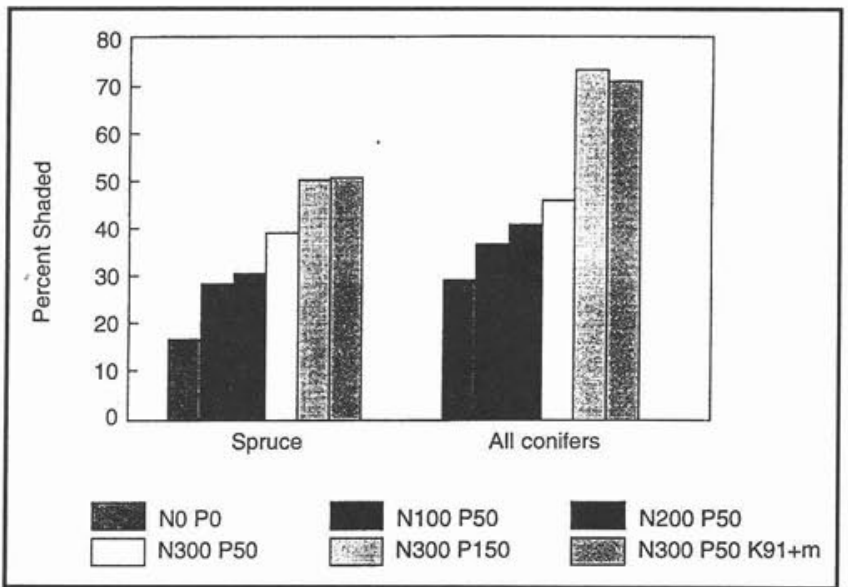

Fig. 3. Crown closure (\%) of conifers in fertilized plots on $\mathrm{CH}$ cutovers.

Control of salal prior to fertilization was recommended to increase the efficiency of fertilizer use by trees.

An assessment of the economics of operational fertilization of $\mathrm{CH}$ cutovers (Thompson and Weetman 1992b) yielded the following conclusions: 1) hemlock fertilization is financially justified, 2) spruce fertilization is financially justified, provided that insect problems do not significantly reduce yield or wood quality, 3 ) cedar fertilization is financially justified if: (a) prices for cedar logs rise at a faster rate than prices for most other species; (b) fertilization releases stands from growth check for longer than five years or (c) cedar stands include at least $10 \%$ hemlock or $25 \%$ spruce, and 4 ) fertilization is financially justified at a discount rate of $3 \%$ when it reduces the rotation by five years and at a discount rate of $5 \%$ when it reduces the rotation by at least 10 years. Since most plantations established on $\mathrm{CH}$ cutovers have a significant component of ingrown hemlock and a response period of at least seven years, fertilization of young plantations with $300 \mathrm{~kg} \mathrm{~N} \mathrm{ha}^{-1}$ and $100 \mathrm{~kg} \mathrm{P} \mathrm{ha}^{-1} \mathrm{can}$ be expected to yield significant financial gains.

Fertilization, Scarification and Planting Density Trials

Two experiments with cedar and hemlock at the time of planting were conducted on both $\mathrm{CH}$ and $\mathrm{HA}$ cutovers (Thompson and Weetman 1992a). The first experiment compared fertilization with no treatment, for hemlock and cedar planted on $\mathrm{CH}$ and $\mathrm{HA}$ cutovers at densities of 500, 1500 and 2500 stems ha ${ }^{-1}$. Each treatment plot contained 64 seedlings and treatments were replicated four times, for a total of 96 plots. On an area basis, the fertilizer dose varied with planting density: $25 \mathrm{~kg} \mathrm{Nha}^{-1}, 6.25 \mathrm{~kg} \mathrm{P} \mathrm{ha}^{-1}$ and $12.5 \mathrm{~kg} \mathrm{~K} \mathrm{ha}^{-1}$ at $2500 \mathrm{stems}$ $\mathrm{ha}^{-1}, 60 \%$ as much at 1500 stems ha $^{-1}$ and $20 \%$ as much at 500 stems ha-1. In the second experiment, the treatments were fertilization and scarification, with density constant at 2500 stems ha ${ }^{-1}$. Each treatment combination was replicated four times for a total of 64 plots. The fertilizer dose was $10 \mathrm{~g} \mathrm{~N}$, $2.5 \mathrm{~g} \mathrm{P}$ and $5 \mathrm{~g} \mathrm{~K}$ per tree. Soil was scarified with a backhoe to a depth of $0.5 \mathrm{~m}$; this treatment also removed salal.

Height growth after five years differed between species and between $\mathrm{CH}$ and HA sites. Hemlock on HA sites was unaffected by treatment and grew more rapidly than hemlock on $\mathrm{CH}$ sites or cedar on either site type. Untreated hemlock on $\mathrm{CH}$ sites grew the least, particularly at the highest planting 
density. Hemlock on $\mathrm{CH}$ sites was very responsive to both fertilization and scarification. Cedar growth differed little between site type or planting density. Both scarification and fertilization resulted in modest increases in growth on either site. Foliar $\mathrm{N}$ concentration was strongly correlated with growth of both species. Mixing of soil mineral and organic horizons through scarification did not increase nutrient availability (Keenan et al. 1994), indicating that decomposition of humus was limited more by its poor quality than by soil microclimate.

\section{Organic Fertilization Trials}

Two trials were established in plantations on $\mathrm{CH}$ cutovers to test the efficacy of a variety of organic wastes for improving the growth and nutrition of trees. In the first trial (Weetman et al. 1993), the response of nine-year-old cedar, hemlock and amabilis fir in plots treated with municipal sewage sludge from Vancouver was compared with response in plots treated with $\mathrm{N}+\mathrm{P}$ fertilizer and untreated controls. Sewage sludge was applied at $500 \mathrm{~kg} \mathrm{~N} \mathrm{ha}^{-1}$ and $133 \mathrm{~kg} \mathrm{P} \mathrm{ha}^{-1}$; fertilizer was applied at $225 \mathrm{~kg} \mathrm{~N} \mathrm{ha}^{-1}$ as ammonium nitrate and $75 \mathrm{~kg} \mathrm{Pha}^{-1}$ as triple super phosphate. The higher loadings of sewage sludge were designed to compensate for much of the $\mathrm{N}$ and $\mathrm{P}$ being bound in organic matter. The trial was replicated in three blocks, each of which contained four $15 \times 15 \mathrm{~m}$ plots of each tree species. During the first growing season, height growth of trees in plots of all three species treated with sludge or inorganic fertilizer was two to three times that in control plots. Nitrogen concentrations in foliage were also two to three times those in control plots, and were highest in N + P fertilized plots. After three years, growth was still enhanced in trees of all three species fertilized with sewage sludge or N+P (Brown 1994).

In the second trial (McDonald et al. 1994) in a nine-yearold cedar plantation on the same $\mathrm{CH}$ cutover, several organic wastes were applied: sewage sludge, sewage sludged mixed with pulp sludge, fish silage mixed with wood ash, silage and ash mixed with pulp sludge, wood ash alone, and inorganic $\mathrm{N}+\mathrm{P}$ fertilizer. Organic wastes were applied at about $500 \mathrm{~kg}$ $\mathrm{Nha}^{-1} ; \mathrm{N}+\mathrm{P}$ fertilizer was applied at $225 \mathrm{~kg} \mathrm{~N} \mathrm{ha}^{-1}$ and 75 $\mathrm{kg} \mathrm{Pha}{ }^{-1}$. All of the additions except wood ash increased height and diameter of cedar trees (Fig. 4). The greatest height growth during the three years after treatment was in the $\mathrm{N}+$ $\mathrm{P}$ fertilized plots, followed by the plots treated with silage and sewage sludge. Mixing with pulp sludge reduced the response to sludge or silage. Wood ash alone suppressed tree growth. During the third growing season, height and diameter increment remained high in the plots treated with fish silage (with and without pulp sludge), but declined in other treatments (Brown 1994).

\section{Burning, Cultivation and Weed Control}

A trial was established in 1982 to evaluate the effects of burning, cultivation and weed control on growth of hemlock, amabilis fir and cedar on $\mathrm{CH}$ sites (Barker, unpublished data). Treatments were burned, unburned $\times$ cultivated, uncultivated $\times$ weed control, no weed control. Plots were cultivated to $0.75 \mathrm{~m}$ depth using a rake attachment to a backhoe. Plots receiving weed control (salal suppression) were sprayed with Garlon $4 \mathrm{E}$ at $2.5 \mathrm{~kg}$ active ingredient ha $\mathrm{h}^{-1}$. Cedar, hemlock and amabilis fir were planted in $7 \times 7$ tree blocks at $2.8 \mathrm{~m}$ spacing. Foliar samples were collected three growing seasons

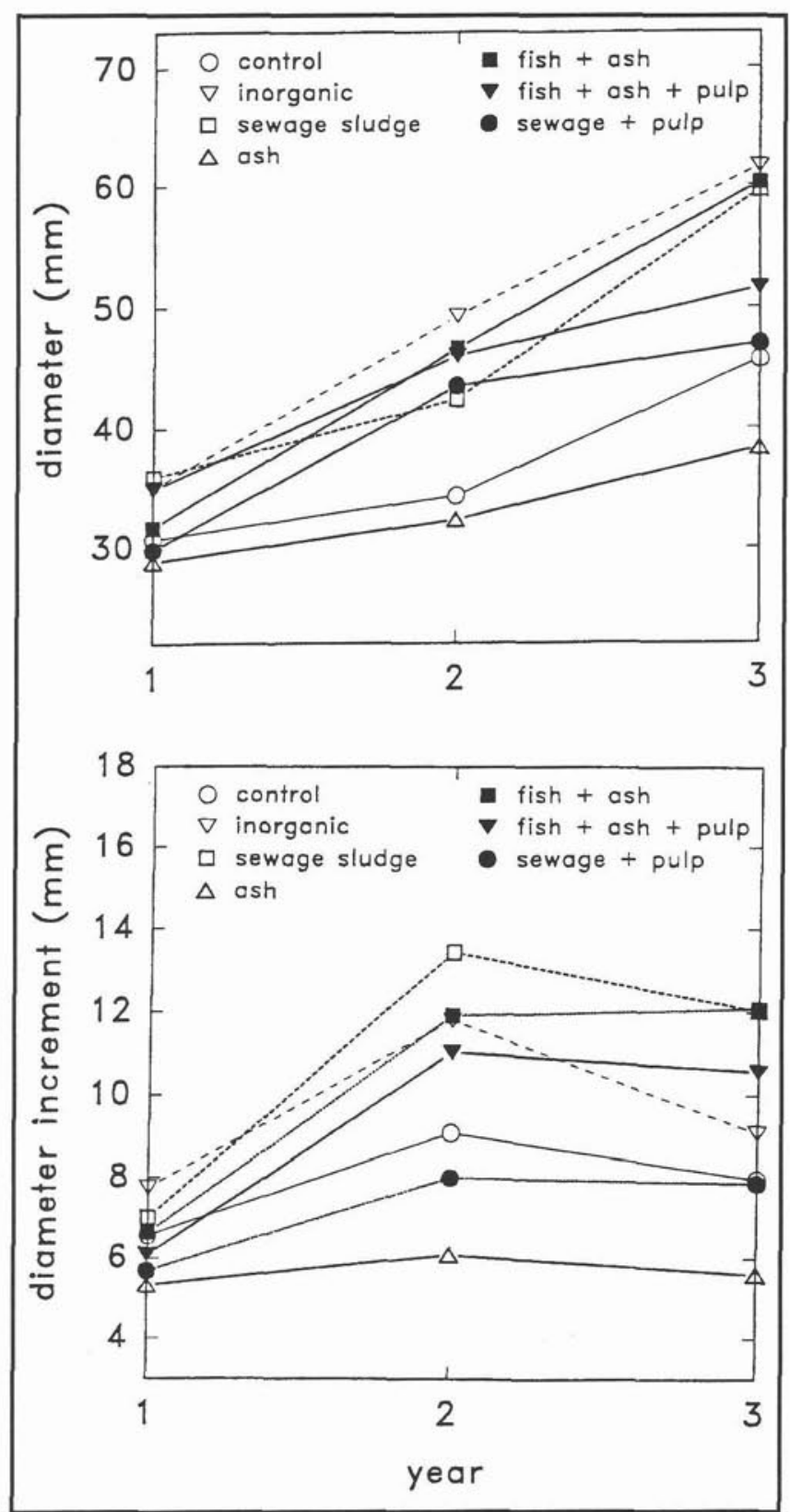

Fig. 4. Diameter growth of cedar trees on $\mathrm{CH}$ cutovers treated with organic wastes. Each value is the mean of 25 trees.

after planting and concentrations of $\mathrm{N}$ and $\mathrm{P}$ were measured. Height and root collar diameter were measured after four growing seasons. Live salal cover was measured prior to treatment and after three growing seasons.

Growth, survival and foliar $\mathrm{P}$ concentrations of all three species were greater in burned plots. Cedar and amabilis fir had significantly higher foliar $\mathrm{N}$ concentrations on burned sites, but hemlock had lower foliar $\mathrm{N}$ concentrations on burned sites. Burning resulted in elevated foliar $P$ concentrations in all three species and significantly higher rates of growth and survival. Cultivation increased tree growth on unburned sites, probably as a result of salal removal. Foliar $\mathrm{N}$ concentrations in amabilis were greater on cultivated sites; foliar $\mathrm{P}$ concentrations in cedar were lower on burned sites. The herbicide damaged 
seedling foliage and did not kill the salal which resprouted from rhizomes following treatment. All three treatments reduced salal from $30-34 \%$ cover in control plots to $19 \%$ by burning, $27 \%$ by cultivation, and $18 \%$ by herbicide application. Averaging all species and treatment combinations, relative growth rate was increased $42 \%$ by burning, $12 \%$ by cultivation, and $2 \%$ by weed control.

\section{Salal Eradication}

An experiment was initiated in 1984 to examine the effects of salal removal and fertilization on spruce, cedar and hemlock trees on CH sites (Weetman et al. 1989a, 1989b). The experimental design was $2 \times 3 \times 2$ factorial: $(\mathrm{S} 0, \mathrm{~S} 1) \times(\mathrm{N} 0, \mathrm{~N} 1, \mathrm{~N} 2)$ $\times(\mathrm{P} 0, \mathrm{P} 1)$, where $\mathrm{S} 0=$ intact salal, $\mathrm{S} 1=$ salal removed, $\mathrm{N} 0=$ control, $\mathrm{N} 1=250 \mathrm{~kg} \mathrm{~N} \mathrm{ha}^{-1}$ as ammonium nitrate, $\mathrm{N} 2=250$ $\mathrm{kg} \mathrm{Nha}^{-1}$ as urea, $\mathrm{P} 0=$ control and $\mathrm{P} 1=100 \mathrm{~kg} \mathrm{P} \mathrm{ha}^{-1}$ as triple superphosphate. Fertilizers were applied in April 1985. Salal was manually removed in 1985 from thirty $25 \times 25 \mathrm{~m}$ ha plots and left in situ. Intact salal roots were treated with Garlon 4E (3.5 $\mathrm{kg}$ active ingredient ha ${ }^{-1}$ ) at the end of the second growing season to prevent resprouting. The effects of salal removal on conifer height and diameter increment were assessed after three growing seasons.

Foliar $\mathrm{N}$ concentrations for all three species in salal removal plots were significantly higher than in control plots, but foliar $\mathrm{P}$ concentrations were unaffected by salal removal. Three-year height increments for spruce, hemlock and cedar were greater in plots from which salal was removed. Cedar response was more closely related to salal removal, while hemlock response was more closely related to fertilization.

\section{Lime and Starch Amendments}

The possibility that rates of $\mathrm{N}$ mineralization in $\mathrm{CH}$ humus could be stimulated by adding available carbon in potato starch or by raising the $\mathrm{pH}$ by adding lime, was addressed in field and laboratory experiments (Prescott and McDonald 1994). Lime was applied to a $\mathrm{CH}$ cutover at a rate of $2500 \mathrm{~kg}$ $\mathrm{ha}^{-1}$, and fertilizer was applied at $275 \mathrm{~kg} \mathrm{~N} \mathrm{ha}^{-1}$ as urea and $75 \mathrm{~kg} \mathrm{Pha}^{-1}$ as triple superphosphate, in a randomized complete block design in 1989 . There were three $30 \times 30 \mathrm{~m}$ plots of each treatment: control, limed, fertilized, and limed plus fertilized. Four years after application, trees in fertilized plots had longer leaders and were greener in colour, but there were no visual effects of the lime additions. The effects of lime and $\mathrm{N}$ $+\mathrm{P}$ fertilizer were also tested in a greenhouse bioassay. Seedlings of cedar, hemlock and Sitka spruce were grown in pots of $\mathrm{CH}$ humus to which lime and fertilizer had been applied at rates approximating $5000 \mathrm{~kg}$ lime ha ${ }^{-1}, 225 \mathrm{~kg} \mathrm{~N}$ $\mathrm{ha}^{-1}$ and $75 \mathrm{~kg} \mathrm{Pha}^{-1}$. After 1.5 years, the biomass of seedlings of all three species was significantly greater in pots that received fertilizer (with or without lime), but there was no effect of lime.

In a field trial on a $\mathrm{CH}$ cutover, potato starch was added combined with $\mathrm{N}$ fertilizer. Four years later, the trees that received fertilizers had longer leaders and greener foliage, but there were no visual effects of starch addition. The effects of starch and glucose additions were also tested in a laboratory incubation. Five-gram samples of humus $(\mathrm{H}$ and $\mathrm{Hw}$ ) from a $\mathrm{CH}$ cutover were amended with $354 \mathrm{mg}$ of potato starch and incubated in the lab for 36 days. There was no effect of the starch addition on the rates of net $\mathrm{N}$ mineralization or $\mathrm{CO}_{2}$ evolution in $\mathrm{H}$ or
Hw samples. Addition of glucose, a simpler $\mathrm{C}$ compound, stimulated microbial activity and decreased $\mathrm{N}$ availability in $\mathrm{CH}$ humus. These experiments indicated that additions of starch or lime would not improve rates of $\mathrm{N}$ mineralization in humus in $\mathrm{CH}$ cutovers.

\section{Response to Clearcutting}

The origin of the growth check of conifers on $\mathrm{CH}$ cutovers was investigated by comparing nutrient availability on $\mathrm{CH}$ and $\mathrm{HA}$ sites and across a chronosequence of $\mathrm{CH}$ sites. Allelopathic effects and mycorrhizal interactions of salal and conifers were examined to determine if they play a role in the dominance of salal on $\mathrm{CH}$ sites.

\section{Soil Nutrient Availability}

Weetman et al. (1990) found that extractable and mineralizable $\mathrm{N}$ generally declined on $\mathrm{CH}$ sites from year 1 to year 8 after burning. Messier (1993) compared $\mathrm{CH}$ sites two and eight years after burning, and reported declines in total $\mathrm{N}$ and extractable $\mathrm{P}$, and a decrease in P retained in ion-exchange resin bags. HA sites two years after burning had higher rates of cellulose decomposition than two-year post-burning $\mathrm{CH}$ sites, but lower total N. Cade-Menun (1995) examined P availability in soil from $\mathrm{CH}$ cutovers immediately, five years and 10 years after clearcutting and burning. There was a flush of available (Bray-extractable) P immediately after burning, which declined during the next 10 years, and a decline in total $\mathrm{P}$ during the 10 years. Foliar nutrient concentrations of salal and fireweed also declined over time in $\mathrm{CH}$ cutovers; $\mathrm{N}$ declined steadily over the eight years, whereas $\mathrm{P}$ and $\mathrm{K}$ reached minimum values within two or three years.

Seedling growth performance was used as a bioassay of soil fertility on different aged cutovers and different site types $(\mathrm{CH}$ and HA) in several experiments. Messier (1993) planted oneyear-old nursery-grown seedlings of hemlock, cedar, and Sitka spruce on HA sites two years after burning, and on $\mathrm{CH}$ sites two and eight years after burning. Light competition was prevented by clipping back the competing vegetation. Height and diameter growth of western red cedar was not affected by time since burning on the $\mathrm{CH}$ site (two-eight years), or by differences between $\mathrm{CH}$ and HA sites on the two-year post-burning sites. In contrast, growth of hemlock and Sitka spruce were greatest on the $\mathrm{HA}$ site, followed by the young $\mathrm{CH}$ site, and least on the oldest $\mathrm{CH}$ site. Spruce and cedar seedlings were grown for two growing seasons in pots containing forest floor material from the same sites used in the field bioassay. The greatest height and diameter growth during the two growing seasons was in forest floors from two-year HA sites. These results confirmed the field seedling bioassay results, suggesting that nutrient availability is in the order two-year postburning $\mathrm{HA}>$ two-year $\mathrm{CH}>$ eight-year $\mathrm{CH}$, and that cedar is relatively insensitive to nutrient availability.

A greenhouse trial was conducted to monitor soil $\mathrm{P}$ availability in a $\mathrm{CH}$ chronosequence (McDonald, unpublished data). Seedlings of Sitka spruce and western red cedar were grown for one year in pots containing soils from a chronosequence of $\mathrm{CH}$ cutovers, one year, four years and eight years after burning, and from an old-growth $\mathrm{CH}$ forest. The aboveand belowground biomass, nutrient concentrations and P-32 uptake of each seedling were measured. Estimates of the size of the labile P pool were made by isotopically exchange- 


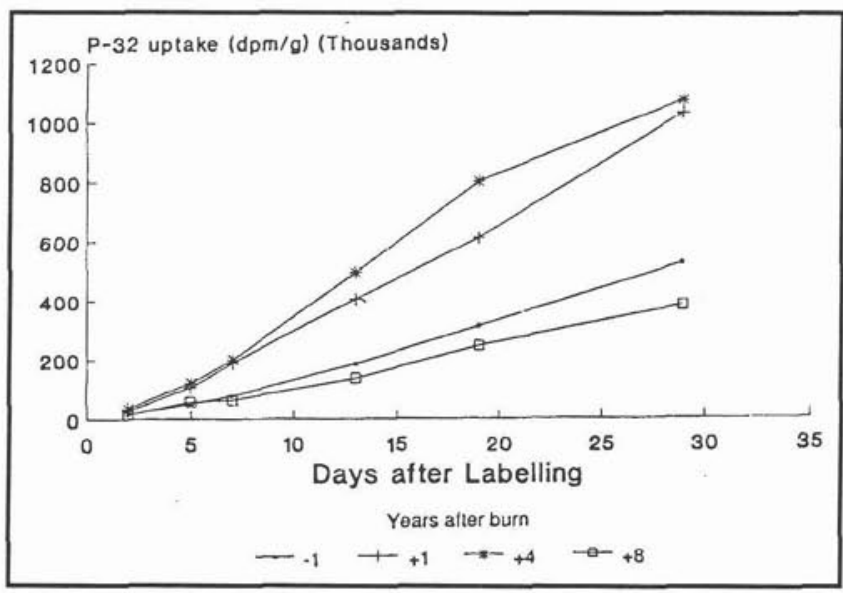

Fig. 5. P-32 uptake by seedlings grown in soils from an old-growth $\mathrm{CH}$ forest and from 1-, 4- and 8-year post-burning $\mathrm{CH}$ sites.

able P (I.E.P.). The P-retention capacity of the soil was estimated by adding $P$ solutions. The results are summarized (Figs. 5 and 6). Seedlings grown in the one- and four-year post-burning soils took up the most P-32. Seedlings grown in the eight-year post-burning soils took up the least P-32, in spite of a greater demand, as reflected in lower foliar $\mathrm{P}$ concentrations and less biomass production. The eight-year post-burning soil also had the greatest capacity to fix P and the smallest labile pool. This suggests the $\mathrm{P}$ deficiency in $\mathrm{CH}$ cutovers arises at least partly through fixation of $\mathrm{P}$ in these soils.

The $\mathrm{C}$ and $\mathrm{N}$ contents of the microbial biomass in a chronosequence of $\mathrm{CH}$ sites (three and 10 years after burning, and old-growth) were measured in fumigation experiments in the laboratory (Chang et al. 1995). Microbial C and N content were greater in the old-growth forest than in the cutovers. The least extractable $\mathrm{N}$ and the greatest microbial $\mathrm{C}: \mathrm{N}$ ratio were in the 10-year cutover. The results of these studies support the hypothesis that a significant component of the growth problem on $\mathrm{CH}$ sites is a rapid decline in soil nutrient availability during the decade following harvesting and burning.

\section{The Role of Salal}

Several experiments were conducted to determine the role of salal in contributing to growth check of conifers on $\mathrm{CH}$ cutovers. Messier and Kimmins $(1990,1991)$ estimated the biomass and nutrient content of competing vegetation in a $\mathrm{CH}$ chronosequence two, four and eight years after clearcutting and slashburning. Between two and eight years, the above- and belowground biomass and $\mathrm{N}$ and $\mathrm{P}$ contents of competing vegetation increased exponentially. At least $70 \%$ of the biomass at each time was salal. By eight years, the biomass of competing vegetation averaged about $17,000 \mathrm{~kg} \mathrm{ha}^{-1}$, which contained

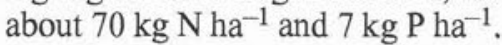

In the field trial with cedar, hemlock and spruce seedlings on two-year HA and two- and eight-year CH sites, Messier (1993) included a vegetation-removal treatment. A $200 \mathrm{~cm}$ patch around each seedling was kept free of competing vegetation by continuously clipping aboveground parts and trenching to 40 $\mathrm{cm}$ around the perimeter. After three growing seasons, the height and diameter of seedlings of all three species on all sites were greater in the vegetation-removed plots. Cedar grew more

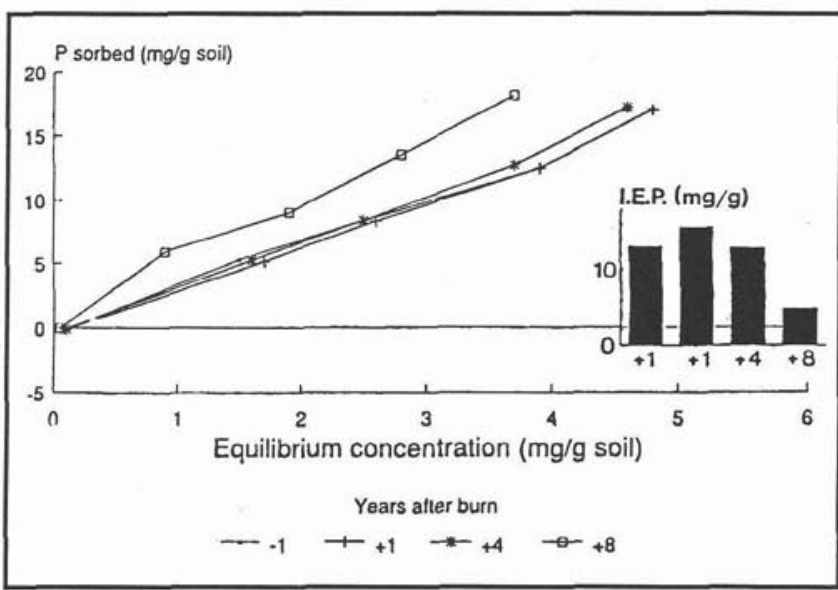

Fig. 6. $\mathrm{P}$ sorption and isotopically exchangeable P (I.E.P.) in soils from an old-growth $\mathrm{CH}$ forest and from 1-, 4- and 8-year postburning $\mathrm{CH}$ sites.

slowly and was less affected by removal of competing vegetation than were spruce and hemlock. Removal of competing vegetation also increased soil temperatures by $1-3^{\circ} \mathrm{C}$ and the availability of $\mathrm{N}$ and $\mathrm{P}$ in resin bags.

Allelopathic effects of salal were assessed by deMontigny (1992). Tannins, thought to be either a procyanidin or a procyanidin and prodelphinidin mixture, were identified in the leaves, roots, flowers, berries and litter of salal using C-13 NMR. Tannins are known to reduce the biodegradability and humification of organic matter. Phenolic acid concentrations in humus from $\mathrm{CH}$ forests were significantly higher in syringic, $\mathrm{p}$-coumaric and ferulic acids, all of which have inhibited root ion uptake in laboratory experiments. In a laboratory bioassay, phenolic acid solutions at field concentrations, and a 5\% solution of salal flower and berry (unbuffered) significantly reduced the germination of Sitka spruce and cedar seeds. Seedlings of spruce, cedar and hemlock watered with the salal leachate solution had significantly lower biomass than the control seedlings after 12 weeks. Root samples of mature cedar and hemlock were placed into the treatment solutions augmented with a P-32 labelled phosphorus solution. The phenolic acid solution reduced $\mathrm{P}$ uptake by cedar and hemlock to $36 \%$ and $69 \%$ (respectively) of that of controls. The salal leachate solution had an even more pronounced effect, reducing P uptake by cedar and hemlock to $15 \%$ and $9 \%$ (respectively) of that of controls.

\section{Mycorrhizal Interactions of Salal, Cedar and Hemlock}

A greenhouse trial was conducted to examine the influence of salal on growth and mycorrhizal colonization of cedar seedlings (Husted, unpublished data). One-year-old nursery stock cedar seedlings were planted in pots containing humus from an eight-year post-burning $\mathrm{CH}$ cutover. The four treatments were: 1) one cedar per pot, 2) two cedars per pot, 3 ) one cedar and one salal seedling per pot, and 4) one cedar and one salal with root systems separated by a wooden divider. After two growing seasons, relative growth rate and $\mathrm{N}$ and $\mathrm{P}$ contents were reduced in cedars grown in competition with cedar or salal. Colonization of cedar roots with mycorrhizal (VAM) fungi was reduced by $10 \%$ in pots containing salal compared to pots containing either one or two cedars. In partitioned pots, VAM colonization was similar in all treatments. These results 
suggested that the presence of salal roots reduced mycorrhizal colonization and nutrient uptake by cedar seedlings.

Additional studies were conducted to determine: 1) the forms of salal mycorrhizae, 2) if mycorrhizae enable salal to use organic $\mathrm{N}$, and 3) if salal mycorrhizae are antagonistic to those of hemlock (Xiao 1994). Salal formed typical ericoid mycorrhizae, characterized by a weft of hyaline hyphae on the surfaces of root hairs and crowded hyphal complexes inside the outer layer of cortical cells (Xiao and Berch 1993). The ability of the four species of ericoid mycorrhizal fungi, isolated from salal roots, to use different forms of organic $\mathrm{N}$ was tested in pure culture or in association with salal. The organic forms of $\mathrm{N}$ applied were glutamine (an amino acid), glutathione (a peptide), and bovine serum albumin (BSA, a protein). The mycorrhizal plants of salal inoculated by all four fungi had higher colonization rate on glutathione or BSA than on ammonium or glutamine. The ericoid mycorrhiza formation of salal was suppressed by application of ammonium and simple organic $\mathrm{N}$, and favoured by more complex organic $\mathrm{N}$. Interactions between species of four ericoid mycorrhizal fungi and three ectomycorrhizal fungi of western hemlock were examined in pure culture. All three ectomycorrhizal fungi were inhibited by ericoid mycorrhizal fungi, but none of the four ericoid mycorrhizal fungi were inhibited by any of the ectomycorrhizal fungi.

These studies demonstrated that salal competes with conifers for nutrients and interferes with nutrient uptake by producing tannins and phenolic acids. Mycorrhizal fungi of salal also contribute to its dominance on $\mathrm{CH}$ sites by providing access to organic forms of $\mathrm{N}$ and by reducing the growth of hemlock seedlings through inhibition of their mycorrhizal fungi.

\section{The Forests}

Studies of the two forest types, $\mathrm{CH}$ and $\mathrm{HA}$ were undertaken to determine: 1) if the low $\mathrm{N}$ and $\mathrm{P}$ supply in $\mathrm{CH}$ cutovers was present in old-growth $\mathrm{CH}$ forests, and 2) the origins of differences in $\mathrm{N}$ and $\mathrm{P}$ availability between the two forest types.

Possible origins of the differences in $\mathrm{N}$ availability that were investigated were: 1) more $\mathrm{N}$ is bound in humus and woody debris in $\mathrm{CH}$ forest floors so that less $\mathrm{N}$ is cycling and available;

2) decomposition of litter is slower in $\mathrm{CH}$ forests, resulting in slow rates of $\mathrm{N}$ mineralization; 3 ) the lack of disturbance by windthrow in $\mathrm{CH}$ forests has led to the development of conditions such as poor soil drainage and aeration which inhibit mineralization of $\mathrm{N} ; 4$ ) the forests occupy different sites with respect to soil, climate and topography, which create differences in $\mathrm{N}$ and $\mathrm{P}$ cycling.

Measurements of nutrient availability in $\mathrm{CH}$ and $\mathrm{HA}$ forest floors demonstrated that lower $\mathrm{N}$ and $\mathrm{P}$ availability in $\mathrm{CH}$ forest floors existed prior to clearcutting (Prescott et al. 1993). All layers of $\mathrm{CH}$ forest floors had lower concentrations of total and extractable $\mathrm{N}$ and mineralized less $\mathrm{N}$ during 40day aerobic incubations in the laboratory. Total and extractable $\mathrm{P}$ was lower only in the litter layer of $\mathrm{CH}$ forest floors. Seedlings of cedar, Sitka spruce, hemlock, and amabilis fir grown from seed in forest floor material from $\mathrm{CH}$ forests grew more slowly and took up less $\mathrm{N}$ and $\mathrm{P}$ than did seedlings grown in HA forest floor material during a one-year greenhouse experiment (Fig. 7). Analysis of $\mathrm{P}$ forms by $\mathrm{P}-31$ solution NMR spectroscopy indicated that concentrations of total and available $\mathrm{P}$ were lower in $\mathrm{CH}$ forest floors, and there was less polyphos-

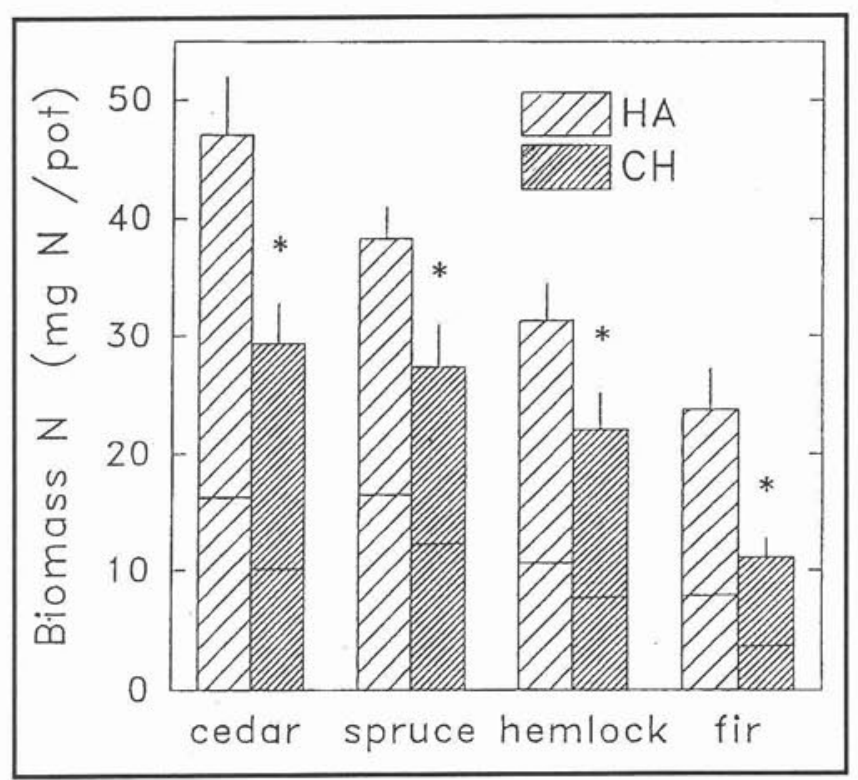

Fig. 7. $\mathrm{N}$ content of seedlings of cedar, spruce, hemlock and amabilis fir grown for 1 year in forest floor $\mathrm{F}$ layer material from $\mathrm{CH}$ and HA forests.

phate and more phosphate in $\mathrm{CH}$ forest floors (Cade-Menun 1995).

There was little evidence to support the hypothesis that more $\mathrm{N}$ and $\mathrm{P}$ were immobilized in detritus in $\mathrm{CH}$ forests, since the total amounts of $\mathrm{N}$ and $\mathrm{P}$ in CWD and forest floors were similar in the two forest types: (2.18 Mg N ha-1 in CH, 2.05 in HA; $142 \mathrm{~kg} \mathrm{P} \mathrm{ha}^{-1}$ in CH, 118.5 in HA) (Keenan et al. 1993). However, there was relatively more $\mathrm{N}$ in the humus $(\mathrm{H})$ layer in $\mathrm{CH}$ forests and less in the $\mathrm{F}$ layer, so the $\mathrm{N}$ may be less available in $\mathrm{CH}$ forests. The greater mass of humus in $\mathrm{CH}$ forests may be the result of their greater age, or less complete decomposition, as discussed below.

Less $\mathrm{N}$ was returned in aboveground litter in $\mathrm{CH}$ forests $(14.2 \mathrm{~kg}$ $\mathrm{N} \mathrm{ha}^{-1}$ ) than in HA forests (35.9), as a result of lower mass and $\mathrm{N}$ concentrations in foliar litter (Keenan et al., in press). There was greater internal recycling within the trees, which resulted from very efficient use of $\mathrm{N}$ by cedar, and from more efficient use of $\mathrm{N}$ by hemlock growing in $\mathrm{CH}$ forests. This is probably a response to low $\mathrm{N}$ availability and could also create a positive feedback that would exacerbate the low $\mathrm{N}$ availability in $\mathrm{CH}$ forest floors.

Decomposition rates of standard litter substrates were similar in the two forest types, and rates of $\mathrm{CO}_{2}$ evolution from each forest floor layer during lab incubations were similar to or greater than those in HA forests (Prescott et al. 1995a). These findings suggest that the decomposition potential of the two sites is similar. The lower $\mathrm{N}$ availability despite similar rates of litter decay may be attributable to the tannins, which bind proteins and immobilize $\mathrm{N}$. There was evidence for tannins in the $\mathrm{CH}$ forest floor $\mathrm{C}-13 \mathrm{NMR}$ spectrum, as indicated by a peak at $145 \mathrm{ppm}$ (deMontigny et al. 1993). The dipolar-dephased $\mathrm{CH}$ spectrum also had higher intensity at $108 \mathrm{ppm}$, another feature diagnostic of tannins. This tannin may be associated with salal; C-13 NMR spectra of salal components indicated high levels of tannin.

The presence of cedar in $\mathrm{CH}$ forests could also contribute to low $\mathrm{N}$ availability. In a modeling study (Keenan et al. 1995), 
there was lower $\mathrm{N}$ availability in forest floors in simulated cedar forests, than in hemlock forests. In trials at the UBC Research Forest (Prescott and Preston 1994), and in Ireland (Prescott et al. 1995b), low rates of $\mathrm{N}$ mineralization were measured in forest floors in cedar plantations, compared with adjacent plantations of other species including hemlock and firs. The relatively low concentrations of $\mathrm{N}$ and high concentrations of waxes and lipids in cedar litter may be responsible for slower $\mathrm{N}$ mineralization in cedar forests.

There was evidence that moisture levels in $\mathrm{CH}$ humus and soil were greater than in HA forests, and this may have resulted in conditions that inhibit decomposition and nutrient cycling in $\mathrm{CH}$ forests. Moisture contents of samples of humus and mineral soils were usually greater in $\mathrm{CH}$ forests, and sensors placed in the humus recorded consistently higher moisture levels in $\mathrm{CH}$ forests. Mineral soil in many of the $\mathrm{CH}$ forests studied was more compacted and cemented layers were continuous and shallower than in HA forests (deMontigny 1992). This could lead to poorer drainage of humus, as indicated by the occurrence of hydromors in $\mathrm{CH}$ forests. There was a lower biomass of fauna and greater representation by aquatic animals such as copepods and brachiopods in $\mathrm{CH}$ humus, also indicative of wetter conditions (Battigelli et al. 1994). The high moisture and smaller faunal biomass could result in less complete decomposition in $\mathrm{CH}$ humus. This was suggested by the higher concentrations of lipids and carbohydrates in $\mathrm{C}-13$ NMR spectra of $\mathrm{CH}$ forest floors and the poorer lignin biodegradation (acid:aldehyde ratio) in $\mathrm{CH}$ forest floors (Prescott et al. 1995a). The poorer drainage in $\mathrm{CH}$ humus may be attributed to the lack of soil disturbance by windthrow, or the tendency for the $\mathrm{CH}$ forests studied to be on lower topographic positions.

\section{Conclusions}

The growth check in conifer regeneration in cutovers of cedarhemlock forests is a consequence of inadequate supplies of $\mathrm{N}$ and $\mathrm{P}$. The low nutrient supply originates in the forest floor of the old-growth cedar-hemlock forests, prior to cutting (Fig. 8). Several factors appear to contribute to low nutrient availability in $\mathrm{CH}$ forest floors, and their relative importance is not clear. Cedar litter, tannins associated with salal, and greater soil water lead to incomplete decomposition and low $\mathrm{N}$ availability in $\mathrm{CH}$ forest floors. Under these conditions, there is more efficient use of nutrients by trees, and less nutrients recycled in litter, which further reduces nutrient availability in the forest floor. These conditions develop over several centuries without severe disturbance, and may be most prevalent on lower slope positions.

After clearcutting there is an assart effect causing a temporary improvement in $\mathrm{N}$ and $\mathrm{P}$ availability for growth of regeneration (Fig. 9). During this period, salal resprouts from rhizomes, immobilizing nutrients in biomass and causing growth check in conifers through $\mathrm{N}$ and $\mathrm{P}$ competition, mycorrhizal antagonisms and release of tannins. The growth check of the conifers can best be relieved by fertilization with additions of $300 \mathrm{~kg} \mathrm{~N}$ ha-1 and $100 \mathrm{~kg}$ P ha-1, or fish silage or sewage sludge. With this treatment, it is hoped that crown closure will be reached after a few years, shading the salal and leading to sustained improvement in the growth rates of conifers.

\section{Acknowledgements}

The research described in this report was conducted by an interdisciplinary team of scientists from University of British Columbia, Canadian Forest Service, B.C. Ministry of Forests

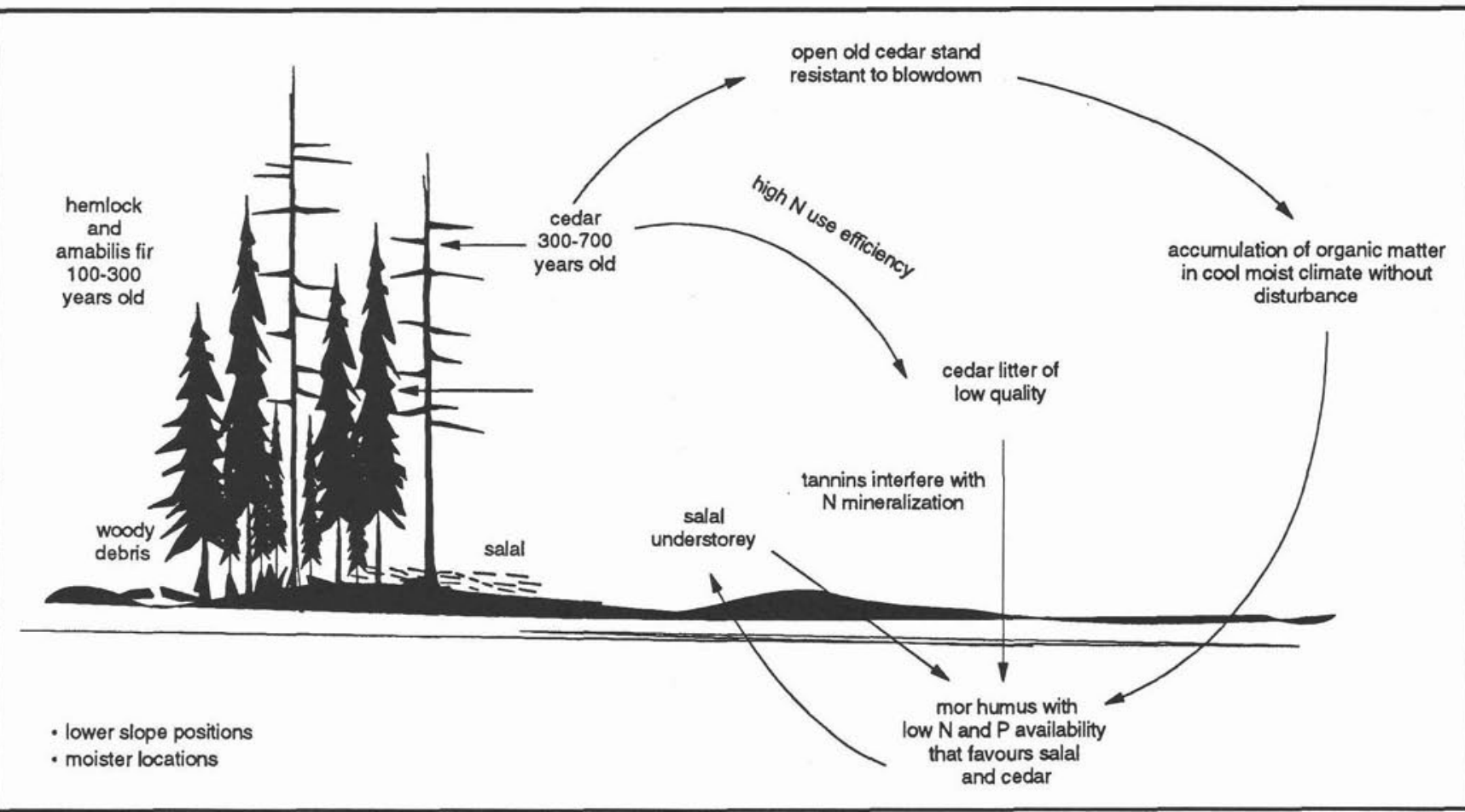

Fig. 8. Development of low nutrient supply in old-growth $\mathrm{CH}$ forests. 


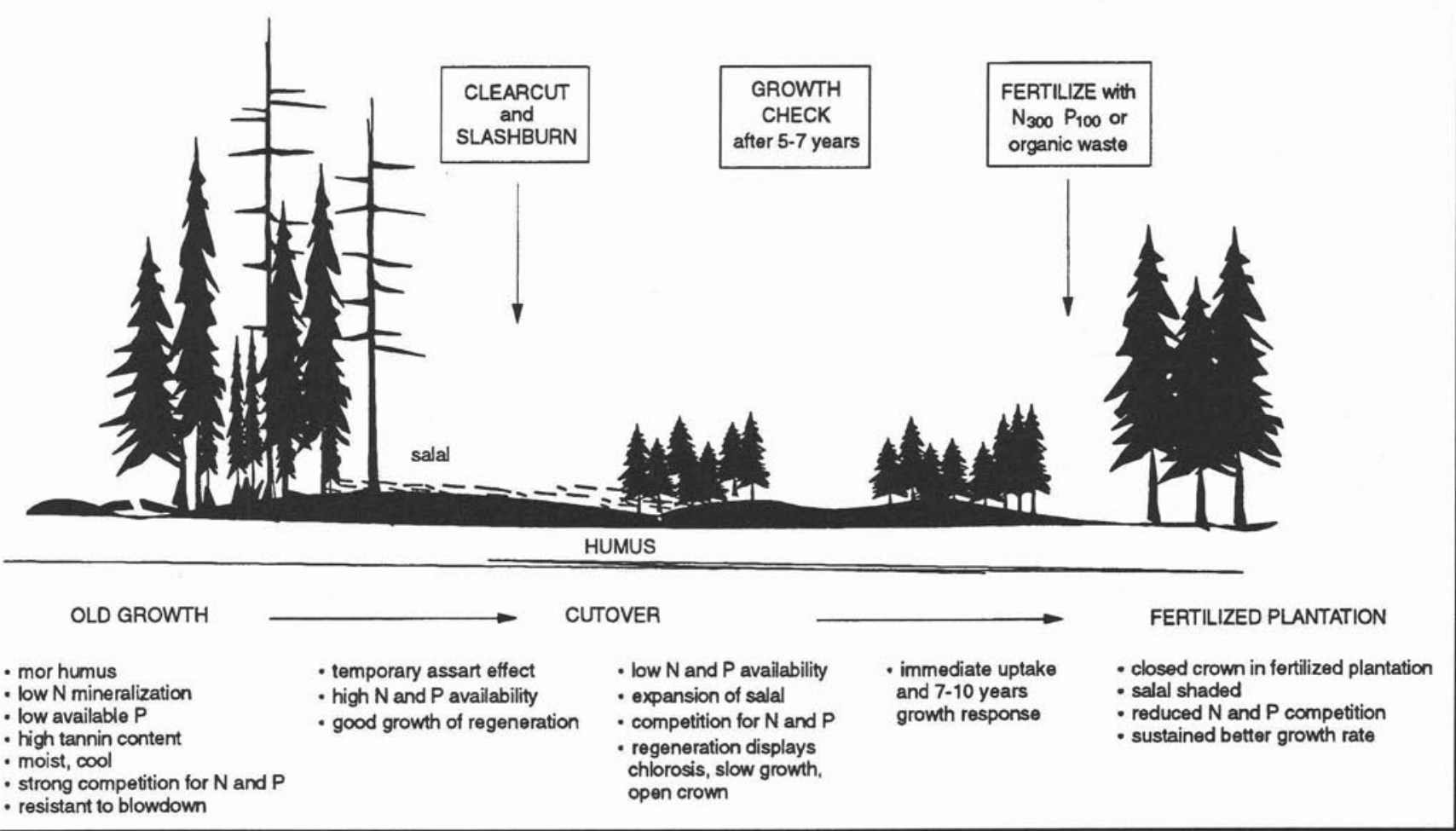

Fig. 9. Strategy for improving conifer growth on $\mathrm{CH}$ cutovers.

and Western Forest Products Ltd., including J. Barker, J. Battigelli, S. Berch, S. Brown, B. Cade-Menun, X. Chang, L. deMontigny, R. Fournier, L. Fraser, A. Germain, B. Hawkins, L. Husted, R. Keenan, J.P. Kimmins, T. Lewis, M. McDonald, C. Messier, C. Prescott, C. Preston, B. Thompson, G. Weetman, and G. Xiao.

Funding for the studies was provided by an NSERC University-Industry Grant, with Western Forest Products Ltd., MacMillan Bloedel Ltd., and Timberwest Ltd., an NSERC Tripartitite Grant, with Canadian Forest Service and Western Forest Products Ltd., and grants from the Science Council of British Columbia, South Moresby Replacement Fund, and the Canada-British Columbia Agreement on Forest Resource Development (FRDA II).

Western Forest Products Ltd. made land available for experiments, and provided accommodation, facilities, and logistical assistance and advice to all researchers. Chemical analyses were provided by MacMillan Bloedel Ltd. The manuscript was typed by P. Quay and improved by the comments of two anonymous reviewers.

\section{References}

Battigelli, J.P., S.M. Berch and V.G. Marshall. 1994. Soil fauna communities in two distinct but adjacent forest types on northern Vancouver Island, British Columbia. Can. J. For. Res. 155-7-1566. Brown, S.M. 1994. Three-year growth responses of western red cedar, western hemlock and amabilis fir to organic fertilizers. B.Sc. Thesis, Forest Sciences Dept., University of British Columbia, Vancouver, BC. 83 p.

Cade-Menun, B. 1995. Phosphorus forms in podzols on northern Vancouver Island. Ph.D. Thesis, Dept. of Soil Science, University of British Columbia, Vancouver, BC.

Carey, M.L. 1977. Nutritional disorders in Sitka spruce in the Republic of Ireland. Ir. For. 34: 40-47.
Chang, S.X., C.M. Preston, K. McCullough, G.F. Weetman and J. Barker. Effect of understory competition on distribution and recovery of ${ }^{15} \mathrm{~N}$ applied to a western red cedar - western hemlock clearcut site. Can. J. For. Res. (in press).

Chang, S.X., C.M. Preston and G.F. Weetman. 1995. Soil microbial biomass and mineralizable $\mathrm{N}$ in a clear-cut chronosequence on northem Vancouver Island, British Columbia. Can. J. For. Res. 25: 1595-1607. deMontigny, L. 1992. An investigation into the factors contributing to the growth check of conifer regeneration on northern Vancouver Island. Ph.D. Thesis, Forest Sciences Dept., University of British Columbia, Vancouver, BC. 191 p.

deMontigny, L.E., C.M. Preston, P.G. Hatcher, and I. Kogel-Knaber. 1993. I. Comparison of humus horizons from two ecosystem phases on northem Vancouver Island using C-13 CPMAS NMR spectroscopy and $\mathrm{CuO}$ oxidation. Can. J. Soil Sci. 73: 9-25.

Germain, A.Y. 1985. Fertilization of stagnated Sitka spruce plantations on northern Vancouver Island. M.F. Thesis, Forest Sciences Dept., University of British Columbia, Vancouver, BC. 185 p.

Keenan, R.J., C.E. Prescott and J.P. Kimmins. 1993. Mass and nutrient content of the forest floor and woody debris in western red cedar and western hemlock forests on northern Vancouver Island. Can. J. For. Res. 23: 1052-1059.

Keenan, RJ., C. Messier and J.P. Kímmins. 1994. Effects of clearcutting and soil mixing on soil properties and understorey biomass in western red cedar and western hemlock forests on northern Vancouver Island, Canada. For. Ecol. Managem. 68: 251-261.

Keenan, R.J, J.P. Kimmins and J. Pastor. 1995. Modelling carbon and nitrogen dynamics in western red cedar and western hemlock forests. In J.M. Kelly and W.W. McFee (eds.), Carbon forms and functions in forest soils. Soil Sci. Soc. Amer., Madison, WI. 594 p. Keenan, R.J., C.E. Prescott and J.P. Kimmins. Litter production and nutrient resorption in western red cedar and western hemlock forests on northern Vancouver Island. Can. J. For. Res. (in press).

Lewis, T. 1982. Ecosystems of the Port McNeill block (Block 4) of Tree Farm Licence 25. Available from Western Forest Products Ltd., 1111 W. Georgia St., Vancouver, BC. 75 p. 
McDonald, M.A., B.J. Hawkins, C.E. Prescott, and J.P. Kimmins. 1994. Growth and foliar nutrition of western red cedar fertilized with sewage sludge, pulp sludge, fish silage and wood ash on northern Vancouver Island. Can. J. For. Res. 24: 297-301.

Messier, C. 1993. Factors limiting early growth of western red cedar, western hemlock and Sitka spruce seedlings on ericaceousdominated clearcut sites in coastal British Columbia. For. Ecol. Managem. 60: 181-206.

Messier, C., T.W. Honer and J.P. Kimmins. 1989. Photosynthetic photon flux density, red:far-red ratio, and minimum light requirement for survival of Gaultheria shallon in western red cedar - western hemlock stands in coastal British Columbia. Can. J. For. Res. 19: 1470-1477. Messier, C. and J.P. Kimmins. 1990. Nutritional stress in Picea sitchensis plantations in coastal British Columbia: the effects of Gaultheria shallon and declining site fertility. Wat. Air Soil Pollut. 54: 257-267. Messier, C. and J.P. Kimmins. 1991. Above- and belowground vegetation recovery in recently clearcut and burned sites dominated by Gaultheria shallon in coastal British Columbia. For. Ecol. Manage. 46: 275-294.

Pojar, J., K. Klinka and D.A. Demarchi. 1991. Coastal western hemlock zone. In D. Meidinger and J. Pojar (eds.), Ecosystems of British Columbia. BC. Ministry of Forests, Victoria, BC. 330 p.

Prescott, C.E., M.A. McDonald and G.F. Weetman. 1993. Availability of $\mathrm{N}$ and $\mathrm{P}$ in the forest floors of adjacent stands of western red cedar-western hemlock and western hemlock - amabilis fir on northern Vancouver Island. Can. J. For. Res. 23: 605-610.

Prescott, C.E. and M.A. McDonald. 1994. Effects of starch and lime additions on mineralization of $\mathrm{C}$ and $\mathrm{N}$ in humus from western red cedar - western hemlock forests on northern Vancouver Island. Can. J. For. Res. 24: 2432-2438.

Prescott, C.E. and C.M. Preston. 1994. Nitrogen mineralization and decomposition in adjacent plantations of western red cedar, western hemlock and Douglas-fir. Can. J. For. Res. 24: 2424-2431.

Prescott, C.E., L.E. deMontigny, C.M. Preston, RJ. Keenan, and G.F. Weetman. 1995a. Carbon chemistry and nutrient supply in cedarhemlock and hemlock-amabilis fir forest floors. pp. 377-396 In Carbon forms and functions in forest soils. J.M. Kelly and W.W. McFee (eds.) Soil Sci. Soc. Amer., Madison, WI.

Prescott, C.E., K.D. Thomas and G.F. Weetman. 1995b. The influence of tree species on $\mathrm{N}$ mineralization in the forest floor: lessons from three retrospective studies. pp. 59-68 In Proc. Trees and Soils Workshop. D.J. Mead and I.S. Cornforth (eds.) Agron. Soc. New Zealand, Special Publication No. 10. Lincoln Univ. Press, Canterbury.
Prescott, C.E. and G.F. Weetman. 1994. Salal Cedar Hemlock Integrated Research Program: A Synthesis. Faculty of Forestry, University of British Columbia, Vancouver. $85 \mathrm{p}$.

Taylor, C.M.A. 1987. The effects of nitrogen fertilizer at different rates and times of application on the growth of Sitka spruce in upland Britain. Forestry 60: 87-99.

Thompson, W.A. and G.F. Weetman. 1992a. Predicting the growth response to fertilization for western hemlock, western red cedar and Sitka spruce on the British Columbia coast. Report for Science Council of BC. 45 p.

Thompson, W.A. and G.F. Weetman. 1992b. Operational fertilization of young stands of cedar, hemlock and spruce on Northern Vancouver Island: Five year results and projected economic impact. Report to the B.C. Ministry of Forests. 51 p.

Weetman, G.F., R. Fournier, J. Barker, E. Schnorbus-Panozzo, and A. Germain. 1989a. Foliar analysis and response of fertilized chlorotic Sitka spruce plantations on salal-dominated cedar-hemlock cutovers on Vancouver Island. Can. J. For. Res. 19: 1501-1511.

Weetman, G.F., R. Fournier, J. Barker, and E. SchnorbusPanozzo. 1989b. Foliar analysis and response of fertilized chlorotic western hemlock and western red cedar reproduction on salal-dominated cutovers on Vancouver Island. Can. J. For. Res. 19: 1512-1520. Weetman, G.F., R. Fournier, E. Schnorbus-Panozzo, and J. Barker. 1990. Post-burn nitrogen and phosphorus availability of deep humus soils in coastal British Columbia cedar/hemlock forests and the use of fertilization and salal eradication to restore productivity. pp. 451-499 In Sustained productivity of forest soils. S.P. Gessel, D.S. Lacate, G.F. Weetman and R.F. Powers (eds) Proc. 7th N. Amer. Forest Soils Conf., Faculty of Forestry, University of British Columbia, Vancouver, BC.

Weetman, G.F., M.A. McDonald, C.E. Prescott, and J.P. Kimmins. 1993. Responses of western hemlock, Pacific silver fir, and western red cedar plantations on northern Vancouver Island to applications of sewage sludge and inorganic fertilizer. Can. J. For. Res. 23: 1815-1820.

Xiao, 1994. The role of root-associated fungi in the dominance of Gaultheria shallon. Dept. Botany, University of British Columbia, Vancouver, BC. 137 p.

Xíao, G. and S.M. Berch. 1993. Ericoid mycorrhizal fungi of Gaultheria shallon. Mycologia 84: 470-471. 